\title{
Records of human occupation from Pleistocene river terrace and aeolian sediments in the Arneiro depression (Lower Tejo River, central eastern Portugal)
}

\author{
Pedro P. Cunha a, ${ }^{a}$, Nelson A.C. Almeida ${ }^{b}$, Thierry Aubry ${ }^{c}$, António A. Martins ${ }^{\mathrm{d}}$, Andrew S. Murray ${ }^{\mathrm{e}}$, \\ Jan-Pieter Buylaert ${ }^{\mathrm{e}, \mathrm{f}}$, Reza Sohbati ${ }^{\mathrm{e}}$, Luis Raposo ${ }^{\mathrm{g}}$, Leonor Rocha ${ }^{\mathrm{h}}$ \\ a Department of Earth Sciences, IMAR-Marine and Environmental Research Centre, University of Coimbra, Portugal \\ b IGESPAR I.P. Extensão do Crato, rua 5 de Outubro, 33, 7430-137 Crato, Portugal \\ c Fundação Côa Parque/IGESPAR I.P., Rua do Museu, 5150-610, Vila Nova Foz Côa, Portugal \\ ' Centro de Geofísica, Dep. Geociências, University of Évora, Portugal \\ e Nordic Laboratory for Luminescence Dating, Aarhus University, Risø DTU, Denmark \\ ${ }^{\mathrm{f}}$ Radiation Research Division, Risø DTU, Denmark \\ 'Museu Nacional de Arqueologia, Lisboa, Portugal \\ h Departamento de História, University of Évora, Portugal
}

\section{A R T I C L E I N F O}

\section{Article history:}

Received 30 January 2011

Received in revised form 17 February 2012

Accepted 20 February 2012

Available online 28 February 2012

\section{Keywords}

Lower Tejo River

Pleistocene

Middle-Upper Palaeolithic industries

Fluvial terraces

Aeolian sands

\begin{abstract}
A B S T R A C T
In the uppermost reach of the Lower Tejo River (eastern central Portugal), where the river crosses two quartzite ridges that separate the Ródão (upstream) and Arneiro (downstream) depressions, Palaeolithic artefacts have been recovered from three lower river terrace levels and a cover unit of aeolian sands. This paper presents data on the discovery of archaeological artefacts from the terrace levels and the aeolian sands that can be linked to Middle and Upper Palaeolithic industries from new field sites at Tapada do Montinho and Castelejo. The archaeological data when placed in a geomorphological, sedimentary and chronological framework, contribute new information on the understanding of human occupation in western Iberia during coldclimate episodes of the last 62 to $12 \mathrm{ka}$; and especially during the cooler and driest conditions that occurred between 32 and $12 \mathrm{ka}$, when the climate favoured aeolian sediment transport. In the Lower Tejo River, the integration of absolute age datasets with archaeological, geomorphological and sedimentary data indicate that in westernmost Iberia the first appearance of artefacts in river terrace sediments suggests that the earliest marker for human occupation dates from the lower Acheulian (Lower Palaeolithic), probably corresponding to an age of $\sim 340 \mathrm{ka}$. Data also suggest, for the first time, that Acheulian lithic industries were replaced by Middle Palaeolithic ones (namely the Levallois stone knapping technique) by $\sim 160$ ka ( MIS6). Middle Palaeolithic industries were later replaced by Upper Palaeolithic industries at $32 \mathrm{ka}$. The post $32 \mathrm{ka}$ period, dominated by aeolian sediment transport, is related to the onset of cold-dry climate conditions which resulted in low river flow discharges, floodplain exposure and reworking by NW winds. This colddry period is coeval with the disappearance of Megafauna and associated Neanderthal communities, and the replacement of the Middle Palaeolithic industries by Upper Palaeolithic ones in this westernmost part of Europe.
\end{abstract}

(c) 2012 Elsevier B.V. All rights reserved.

\section{Introduction}

The Tejo River (Tajo in Spanish and Tagus in Latin) is the longest river $(1007 \mathrm{~km})$ of the Iberian Peninsula; it flows to the Atlantic Ocean (Fig. 1). Being one of the largest systems of western Europe, the river drains the central part of the Spanish Plateau (Meseta) and several Cenozoic basins (De Vicente et al., 2011), with a catchment area of $81,947 \mathrm{~km}^{2}$ (Benito et al., 2003).

\footnotetext{
* Corresponding author.

E-mail address: pcunha@dct.uc.pt (P.P. Cunha).
}

The long term drainage evolution of the Tejo is recorded in a series of inset river terrace landforms. The number of terraces levels varies spatially and these in turn suggest temporal variability in fluvial incision and aggradations patterns. In Spain, up to twelve terrace levels were identified in the Campo Arañuelo area in the western part of the Madrid Cenozoic Basin (Pérez-González, 1994; Silva et al., 1999). This contrasts with up to twenty three terrace levels of the Jarama, Henares and Manzanares rivers (tributaries of the Tejo), upstream of Toledo, in the centre of the Madrid Basin (Pérez-González, 1994; Santonja and Pérez-González, 1997, 2002; Benito Calvo et al., 1998; Silva et al., 1999). Near Toledo, Pinilla et al. (1995) linked the Matuyama/Brunhes boundary (780 ka) to the T13 terrace (+60 m). In the same sequence, the Middle Pleistocene is recorded in six 


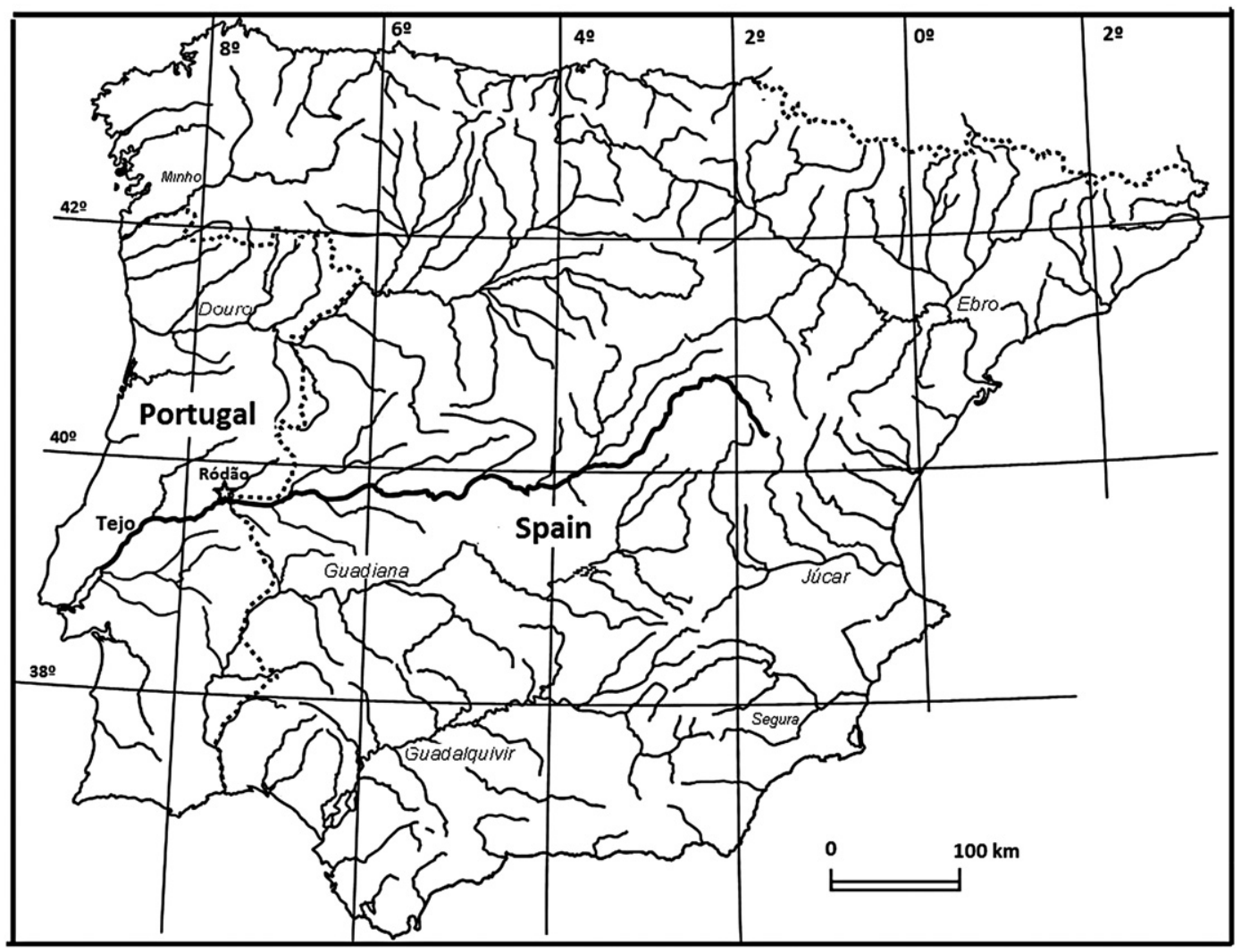

Fig. 1. The main Iberian drainage basins and location of the study area (Ródão).

terrace levels (T13-T18) and the Late Pleistocene in three terrace levels (T19-T21), with the T19 being no older than the Marine Isotope Stage (MIS) 6 (Benito Calvo et al., 1998). The Holocene is recorded in two terraces (T22-T23) near the valley floor (Benito et al., 2003; Santisteban and Schulte, 2007). In the Portuguese sector along the Lower Tejo Cenozoic Basin (Pais et al., 2012), six terrace levels (T1-T6) are inset below the culminant (Pliocene) sedimentary unit (Martins et al., 2010a, 2010b). Luminescence and U-Series dating provided burial ages only for the three lower terraces (e.g. Raposo, 1995a; Cunha et al., 2008; Martins et al., 2009, 2010a, 2010b), due to the high environmental dose rate and the age limitations of the dating techniques used. The T3 terrace is considered to be older than $340 \mathrm{ka}$ (MIS11 or MIS13?), the T4 is ca. 150-340 ka (MIS9-6), the T5 is probably 75-136 ka (MIS5) and the T6 is 62-30 ka (MIS3). A cover unit of aeolian sands and colluvium should post-date the lower terrace levels, spanning 30-12 ka (MIS2).

The formation of the Lower Tejo four younger terraces is interpreted to be related to cyclic glacio-eustatic fluctuations superimposed onto a long term regional uplift trend (Martins et al., 2010a, b). For the alluvial infill (uppermost Pleistocene and Holocene) and the three lowest terraces (T6, T5 and T4), the periods of fluvial aggradation seem to be coincident with sea-level highstands and milder climatic conditions, whilst the periods of fluvial incision coincide with sea-level lowstands and cold climate conditions (Martins et al, 2010a,b). This pattern of climate-eustatic related forcing of fluvial aggradation and incision is observed for many fluvial systems in NW Europe and indeed worldwide (Bridgland et al., 2007 and references therein).

In Spain, the Tejo River and tributaries preserve a very large number of archaeological materials in the lower terraces and associated colluviums. Namely, the $+60 \mathrm{~m}$ terrace of the Sangrera River at San Bartolmé de Las Abiertas (considered equivalent to the upper Tejo terrace T13) contains the oldest Acheulian industries in deposits considered equivalent to the Matuyama/Brunhes boundary (Bridgland et al., 2006). Acheulian industries were found until the upper Tejo terrace T19 (MIS6), by correlation with the upper Henares River (Benito Calvo et al., 1998; Bridgland et al., 2006).

In Portugal, the oldest artefacts (Lower Palaeolithic Acheulian industries) were found at the base of the T4 terrace, which sedimentary record was dated as ca. 300 to $150 \mathrm{ka}$ (Martins et al., 2010a, b). This terrace could correlate with the Henares River T18 terrace (with two ages of: $202 \pm 58 \mathrm{ka}$ and $243 \pm 18 \mathrm{ka}$ ) in the Madrid region (the Upper Tejo). The transition between Lower to Middle Palaeolithic industries is probably recorded within the T4 terrace (Martins et al., 2010b). The T5 and T6 terraces contain widespread Mousterian artefacts, assigned to the Middle Palaeolithic cultural sequences of the Iberian Peninsula, which remained up until the beginning of the Upper Palaeolithic (Raposo, 1995a, b). The T5 terrace of the Lower Tejo probably correlates with the Henares River T19 terrace (with two ages: $103 \pm 8 \mathrm{ka}$ and $135 \pm 12 \mathrm{ka}$ ).

In the context of fluvial terraces, the Upper Palaeolithic industries are less abundant than the Middle Palaeolithic industries (Raposo, 1995b), therefore enhancing the interest of this study. Furthermore, the chronologic sequence dated here covers the Glacial Maximum and the Late Glacial period, providing an opportunity to provide insights in to climate-related controls on fluvial system development and human-fluvial landscape relationships. The high density of Lower to Upper Palaeolithic sites in the uppermost reach of the Lower Tejo River Basin was first identified in 1971 as a result of research carried out by the "Grupo de Estudos do Paleolítico de Portugal" (GEPP). In this reach (Reach I, defined by Cunha et al., 2005), located $\sim 150 \mathrm{~km}$ from the river mouth, the Tejo River crosses the tectonic depressions of Ródão and Arneiro (Fig. 2) having developed extensive river terraces containing the archaeological sites of Monte do Famaco, Vilas Ruivas and Foz do Enxarrique. Excavation of these sites revealed well-established Middle Palaeolithic settlements 


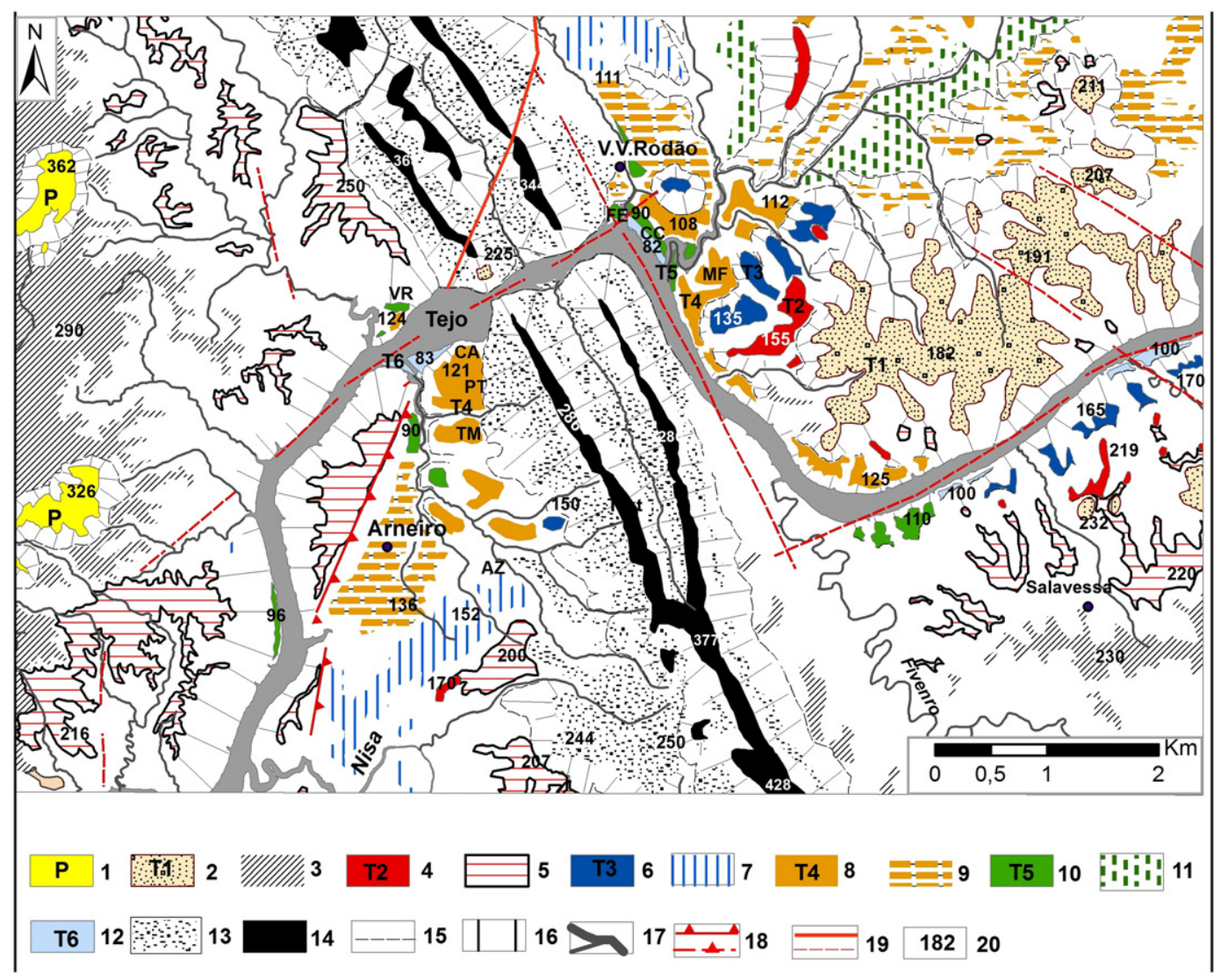

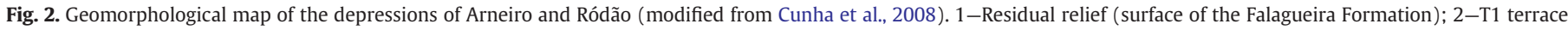

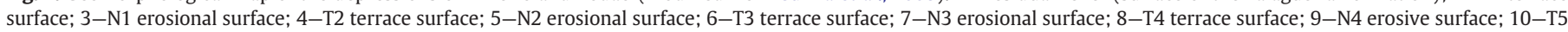

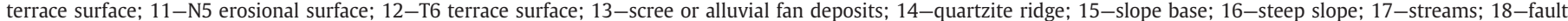

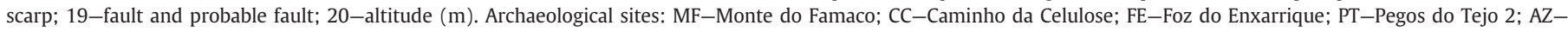
Azinhal; CA-Castelejo; TM-Tapada do Montinho; VR - Vilas Ruivas.

(GEPP, 1977, 1978), placing the region at the forefront of Palaeolithic research in Portugal (Raposo, 1987, 1995b, 2002).

Despite the documented exploitation and distribution of flint cobbles available in the Tejo terrace deposits, data on Upper Palaeolithic occupation in this area were limited and fragmentary, as with other sectors of the Lower Tejo valley (Martins et al., 2010b) and other regions of Portugal (Aubry et al., 2002, 2008, 2010, 2011; Aubry and Bicho, 2006; Zilhão, 2006).

The aim of this paper is to present results of recent geomorphological and archaeological investigations carried out in the Arneiro depression (Figs. 1 and 2). These data are integrated with published results from the upstream Ródão depression (Cunha et al., 2008). Collectively, the results from Arneiro and Ródão depressions provide an improved understanding of the chronology of the Lower, Middle and Upper Palaeolithic human occupation and resource exploitation, as well as environmental conditions and landscape evolution during the Middle-Late Pleistocene of western Iberia. Previous interpretations of archaeological data and fluvial archives in this area have been constrained by poor chronology. The archaeological investigation, when combined with geomorphological mapping and the use of both quartz and feldspar luminescence dating of the rock surfaces of fluvial quartzite cobbles, provide a new chronological framework.

\section{Materials and methods}

The information presented here is derived from stratigraphic, archaeological and chronological data collected from recently studied sites in the Arneiro depression, using a standard geoarchaeological fieldwork approach: a geomorphological study of each site and its surroundings and the generation of detailed maps using GIS, a field description and stratigraphic correlation of the deposits, and the selection and sampling of materials for absolute dating.

Fieldwork has included the systematic description of sections in outcrops or trial trenches in order to characterise the stratigraphic successions, their vertical and lateral variations and archaeological contents. Informal geoarchaeological field units (GFU) were identified using a combination of lithostratigraphic, pedological or archaeological criteria. The correlation between the GFU of the several sites rests upon a reconstruction of their genetic processes and the environment of deposition, based on particle size distribution, composition, fabric and structure, archaeological content and dating results.

The archaeological materials, mainly composed of knapped industries (assemblages of stone artefacts made by humans; Texier et al., 1980), were studied from raw-material, technological and typological perspectives. Some of the artefacts are made of local quartzite but the others use lithic materials transported by the river.

Chronology of the GFU was provided by Optical Stimulated Luminescence (OSL). This is a technique that can be used for measuring the time elapsed since sedimentary particles were last exposed to daylight (Duller, 2004). Because of this light sensitivity, the processing of sediment samples took place under subdued red light. Wet sieving was used to separate the $180-250 \mu \mathrm{m}$ grain size fraction, which was then treated using $\mathrm{HCl}(10 \%)$ and $\mathrm{H}_{2} \mathrm{O}_{2}(10 \%)$ to remove carbonates and organic matter, respectively. The K-feldspar $\left(<2.58 \mathrm{~g} / \mathrm{cm}^{3}\right)$ was separated using a heavy liquid solution of sodium polytungstate. 
The outer layer of K-feldspar grains was etched with diluted HF (10\%, $40 \mathrm{~min}$ ), to minimise any contribution from external alpha particles to the dose rate. Finally, $\mathrm{HCl}(10 \%)$ was again used to dissolve any remaining soluble fluorides. Measurement of the equivalent doses (De) was performed on Risø TL/DA-15 and TL/DA-16 readers. OSL ages were derived by dividing the equivalent doses by the total dose rates. Generally, the major drawback of the most lightsensitive part of the quartz OSL signal is that it saturates at $<200 \mathrm{~Gy}$, limiting the age range to $<150 \mathrm{ka}$ (Thomsen et al., 2011). In the Lower Tejo Basin, because of the relatively high dose rates (3-5 Gy/ ka), quartz luminescence was only suitable for the younger samples (less than $\sim 60 \mathrm{ka}$ ). As a result, we decided to work with quartz grains $(180-250 \mu \mathrm{m})$ from all sediment samples and density-separated $\mathrm{K}$ rich feldspar grains (180-250 $\mu \mathrm{m}$ ) for older samples. Quartz dose estimates used a standard UV SAR protocol with a $200{ }^{\circ} \mathrm{C}$ preheat for $10 \mathrm{~s}$, a $180^{\circ} \mathrm{C}$ cut heat, and blue stimulation at $125^{\circ} \mathrm{C}$. Feldspar dose estimates used the IRSL at $50{ }^{\circ} \mathrm{C}$ protocol described by Cunha et al. (2008). Dose rates were determined using high resolution gamma spectrometry on bulk samples (Murray et al., 1987; Olley et al., 1996), and assuming a $\mathrm{K}$ content of $12.5 \pm 0.5 \%$ in $\mathrm{K}$ feldspar. The average dose rate to K-rich grains is $3.4 \mathrm{~Gy} \mathrm{ka}^{-1}(\mathrm{~s}=0.5 \mathrm{~Gy} ; \mathrm{n}=12$ ), with internal $\mathrm{K}$ and $\mathrm{Rb}$ contributing $0.84 \pm 0.04 \mathrm{~Gy} \mathrm{ka}^{-1}$. OSL measurements were also made on six quartzite cobbles $(\sim 8 \mathrm{~cm}$ in diameter) of the Tapada do Montinho site (Fig. 3), carried out on both whole rock slices $(\sim 1.5 \mathrm{~mm}$ thick $)$ and separated quartz grains
(63-300 $\mu \mathrm{m}$ ) recovered from the outer $1.5 \mathrm{~mm}$ surface of the cobbles (Sohbati et al., 2012).

\section{Geomorphological setting}

The Tejo River is a long-lived system ( 3.6 Ma) being an extremely important fluvial record from one of the largest systems of western Europe. In the most upstream sector of the Lower Tejo River Basin (Reaches I and II defined by Cunha et al., 2005), the river crosses two quartzite ridges that separate the Ródão (upstream) and Arneiro (downstream) depressions (Figs. 1 and 2). This region was recently the focus of several studies that were undertaken to improve the understanding of controls on landscape evolution during the Pleistocene (Cunha et al., 2005, 2008). Six Pleistocene fluvial terraces (T1 to T6, from top to down) form a staircase that is inset into a top basin fill surface (P) (Fig. 2 and Table 1). At Monte da Charneca, the earlier T2 complex terrace (consisting of two steps; Cunha et al., 2008) is now subdivided in two distinct levels, labelled as T2 and T3, so they correlate by relative height above the river bed with the terrace levels in the downstream reaches III and IV of the Lower Tejo (Martins et al., 2010b). The fluvial terrace sequence of the Ródão and Arneiro depressions comprises: $\mathrm{T} 1(+111 \mathrm{~m})$; $\mathrm{T} 2(+83 \mathrm{~m})$; $\mathrm{T} 3(+61 \mathrm{~m})$; $\mathrm{T} 4$ $(+34 \mathrm{~m})$; $\mathrm{T} 5(+18 \mathrm{~m})$ and the $\mathrm{T} 6(+10 \mathrm{~m})$. The river bed is at $72 \mathrm{~m}$ above sea level (a.s.l.) immediately upstream of the Ródão gorge, named "Portas de Ródão". Some vertical displacements

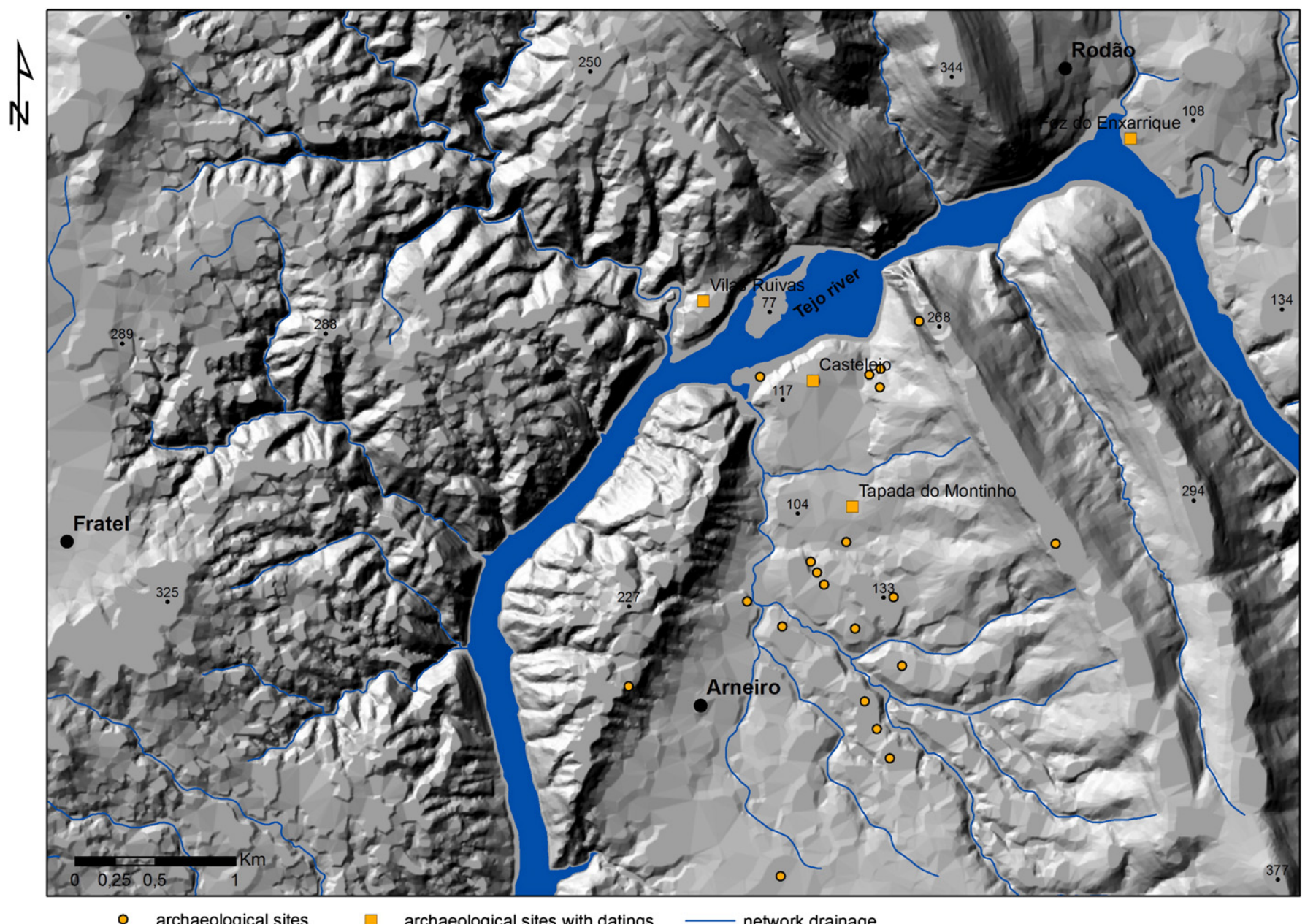

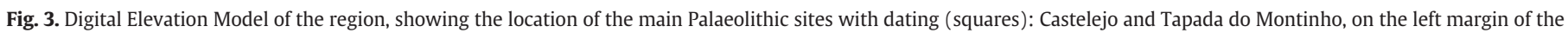
Tejo River; Vilas Ruivas and Foz do Enxarrique, on the right margin (green). Other less important archaeological sites on the left margin are noted (circles). 
affecting terraces were identified; this could be related to some Pleistocene activity of the Ponsul fault and other minor faults coincident with linear reaches of the Tejo River (Fig. 2; Cunha et al., 2008).

\section{Archaeological setting}

In the Ródão depression, several archaeological sites have been excavated in the three lower terraces of the Tejo River (T4, T5 and T6) and their main characteristics are described below. Quartzite and quartz raw material is abundant in the terraces while flint/chert is very rare.

At the Monte do Famaco site (Fig. 2), thirty-four rolled quartzite artefacts have been found in the $0.5 \mathrm{~m}$-thick boulder gravels of the T4 terrace (local surface at $116 \mathrm{~m}$ a.s.l.) and attributed to the early Middle Acheulian (late Lower Palaeolithic) (Raposo and Silva, 1985a, b; Raposo, 1987). More recently, other similar artefacts were found in situ, showing no evidence of later fluvial transport after its deposition in the terrace. At the top of the terrace and in nearby colluvium, 1500 Middle Acheulian quartzite artefacts comprising bifaces, cleavers, scrapers, etc., have been collected, some of them with evidence of wind abrasion but none indicating reworking by fluvial transport (Raposo, 1987).

At the Ródão and Vilas Ruivas locations the base of T4 was dated by Infrared Stimulated Luminescence (IRSL) to $\sim 280 \mathrm{ka}$ (Cunha et al., 2008). The burial age is now considered to be older. The age discrepancy relates to the anomalous fading affecting the OSL signal from feldspars (Wintle, 1973; Spooner, 1992) causing age underestimation. Despite the correction methods (Huntley and Lamothe, 2001; Lamothe et al., 2003), such corrections can be $>30 \%$ and are only applicable to the linear (low dose) part of the dose response curve (Huntley and Lamothe, 2001; Lamothe et al., 2003). Thus, the corrected age of the base of T4 can reach $~ 300-340$ ka (Martins et al., 2010a) and therefore provides some age control for the in situ early Middle Acheulian industries found at the base of T4. The Middle Acheulian industries collected from the T4 top deposits probably date from ca. $180 \mathrm{ka}$, as they occur before the early technologically Middle Palaeolithic lithic remains found in situ in a level located $1 \mathrm{~m}$ bellow the T4 terrace surface at the Pegos do Tejo site (Fig. 3), in the Arneiro depression (Almeida et al., 2008).

At the Caminho da Celulose site (Foz do Enxarrique, Figs. 2 and 3), Mousterian artefacts (Middle Palaeolithic industries) were found in situ (GEPP, 1977; L. Raposo, pers. comm.) in the Senhora da Alagada terrace (T5). From the $2 \mathrm{~m}$ of sediments exposed, two IRSL ages of $136 \pm 10 \mathrm{ka}$ (sample 052204) and $125 \pm 7 \mathrm{ka}(052247)$ and a thermoluminescence (TL) age of $93+20 /-13 \mathrm{ka}$ (sample LTA8) have been reported (Cunha et al., 2008).

The Foz do Enxarrique site (Figs. 2 and 3), on the T6 terrace, provided evidence of a rich in situ Mousterian industry, comprising $\sim 10,000$ pieces of quartzite (67\%), white quartz (23\%) and flint; some of them clearly showing usage of the Levallois technique (Raposo et al., 1985; Raposo and Silva, 1986; Raposo, 1987).

Abundant megafaunal remains (Cervus elaphus, Equus sp., Bos primigenius, Elephas antiquus and a rhinoceros), other mammals (e.g. fox, hyena and rabbit), birds and fish (Cardoso, 1993; Brugal and Raposo, 1999; Raposo, 1999) were found in a level located above a basal boulder gravel ( 0 to $0.5 \mathrm{~m}$-thick) and below very fine sands and silts. U-Series studies of three teeth gave an age of $33.6 \pm$ $0.5 \mathrm{ka}$ for this level (Raposo, 1995a). The $5.5 \mathrm{~m}$ thick bed of very fine sands and silts was dated by IRSL as $39 \mathrm{ka}$ (base) to $32 \mathrm{ka}$ (near the top) (Cunha et al., 2008).

In the Arneiro depression, fourteen Palaeolithic settlements have been identified (Fig. 3), three of which have been subjected to archaeological excavations.

The excavations at the Vilas Ruivas site (GEPP, 1980a, 1980b; Raposo and Silva, 1981, 1982, 1983, 1985c; Raposo, 1987) showed that the T4 terrace deposits consist of $4 \mathrm{~m}$ of compacted reddish 
very coarse gravely sands, yielding six rolled Acheulian type artefacts and a non rolled flake at the base, and a $4 \mathrm{~m}$ thick upper bed of boulder gravels; the terrace surface is at $124 \mathrm{~m}$ a.s.l. The Vilas Ruivas site (Figs. 2 and 3) also contains a sedimentary record of the Vilas Ruivas stream before its capture, incised into the Tejo T4 terrace (Silva et al., 1981). Raposo (1987) has identified archaeological structures as fireplaces with wind screens. The Mousterian industry recovered here, is represented by more than 500 pieces, and includes a large number showing indications of the Levallois knapping technique. Levallois industries are characterised by the abundance of stone flakes extracted from core pebbles. These artefacts were found on a 1 to $0.5 \mathrm{~m}$-thick silt bed overlying a gravel bed 0.2 to $0.5 \mathrm{~cm}$ thick, that provided TL ages of $68 \mathrm{ka}+35 \mathrm{ka} /-26 \mathrm{ka}$ and $51 \mathrm{ka}+13 \mathrm{ka} /-12 \mathrm{ka}$ (Raposo, 1995a). In the same stratigraphic level, Cunha et al. (2008) obtained corrected ages of $113 \pm 6 \mathrm{ka}$ and $105 \pm 5 \mathrm{ka}$, using IRSL at $50{ }^{\circ} \mathrm{C}$. At the surface, a probable Magdalenian (Upper Palaeolithic) flint industry was found associated with a thin cover of aeolian sand (Raposo, 1987).

The Pegos do Tejo 2 site (Fig. 3), at the top of the T4 terrace and at an altitude of $110 \mathrm{~m}$ a.s.l., provided a Levallois core and other materials knapped in local quartzite, including two right angle notches and a cortical knife (Mousterian industries-Middle Palaeolithic; Almeida et al., 2008). A quartz OSL age of $135 \pm 21$ ka (GLL code 050301) was obtained from the archaeological bed, located $1 \mathrm{~m}$ below the top of the T4 terrace. However, the report produced by the Ghent Luminescence Laboratory indicates that the quartz from this sample has a natural dose in the region of the growth curve approaching saturation. So, the $135 \pm 21$ ka should be considered as a minimum age. The IRSL (K-feldspar) corrected age of $129 \pm 8 \mathrm{ka}$ obtained from the top of the T4 terrace at a nearby outcrop (Cunha et al., 2008) is also a minimum age (the real age could be $160 \mathrm{ka}$ ). At that site, the T4 terrace deposits comprise a $1 \mathrm{~m}$ thick basal gravel unit overlain by $12 \mathrm{~m}$ of compacted reddish coarse to medium sands and an uppermost bed of $1 \mathrm{~m}$ of colluvium. At $109 \mathrm{~m}$ a.s.l., the base of the T4 deposits has a disconformable contact with underlying Palaeogene sandstones (Cabeço do Infante Formation; Cunha, 1996).

The Azinhal site (Figs. 2 and 3), on an alluvial unit at an altitude of $150 \mathrm{~m}$ a.s.l., was discovered in 2003 during a survey campaign (Almeida et al., 2008). One of the Palaeolithic artefacts found is a hand axe linked to the Micoquian (a Middle Palaeolithic cultural variant). In the same year, an excavation provided a considerable number of Mousterian artefacts (denticulate flakes, scrapers and a Micoquian hand axe). A quartz OSL age of $61 \pm 2 \mathrm{ka}$ (GLL code 050302) was obtained from the archaeological bed (Almeida et al., 2008).

\section{Geomorphology of the Arneiro depression}

The Arneiro depression is defined by the quartzite ridges to the east and an exhumed fault scarp in the west (Ponsul fault). Several geomorphic elements were identified in the area (Figs. 2 and 3; Table 4) as follows:

a) an alluvial fan at an elevation 234-250 $\mathrm{m}$ a.s.l., considered to be correlative of the $\mathrm{T} 1$ rocky terrace at $225 \mathrm{~m}$ a.s.l. ( $153 \mathrm{~m}$ a.r.b.) in the Portas do Ródão gorge;

b) the $\mathrm{T} 2$ terrace at $180 \mathrm{~m}$ a.s.l. $(+108 \mathrm{~m})$ and the correspondent $\mathrm{N} 2$ erosive surface:

c) the T3 terrace at $180 \mathrm{~m}$ a.s.l. $(+78 \mathrm{~m})$ and the correlative N3 erosive surface:

d) the wide $\mathrm{T} 4$ terrace at $120 \mathrm{~m}$ a.s.l. ( $+48 \mathrm{~m}$ ) and adjacent $\mathrm{N} 4$ erosive surface;

e) the $\mathrm{T} 5$ terrace at $90 \mathrm{~m}$ a.s.l. $(+18 \mathrm{~m})$;

f) the T6 terrace at $82 \mathrm{~m}$ a.s.l. $(+10 \mathrm{~m})$;

g) a $1 \mathrm{~m}$-thick cover unit of aeolian sands, preserved on top of the T4 terrace, with the base at $120 \mathrm{~m}$ a.s.l. (Castelejo hill);

h) the modern alluvial infill of the Tejo valley (river bed at $72 \mathrm{~m}$ a.s.l.).

Based on the geomorphological evidence from the area, the interpreted pattern is an overall fluvial incision trend punctuated by periods of strath enlargement (dynamic equilibrium?) and later terrace aggradation. Incision by the Tejo occurred in distinct phases. Until the deposition of the sediments that constitute the top of the T2 terrace (probably by 500 to $700 \mathrm{ka}$; Fig. 4), the Tejo River was quite large immediately downstream of the Portas do Ródão gorge, as documented by the widespread remains of the fluvial erosive surface that corresponds with the T2 strath and low gradient adjacent slopes (N2 at altitudes of 225 to $180 \mathrm{~m}$ a.s.l.). During the next fluvial downcutting episode, leading to the genesis of T3 and the N3 surface,

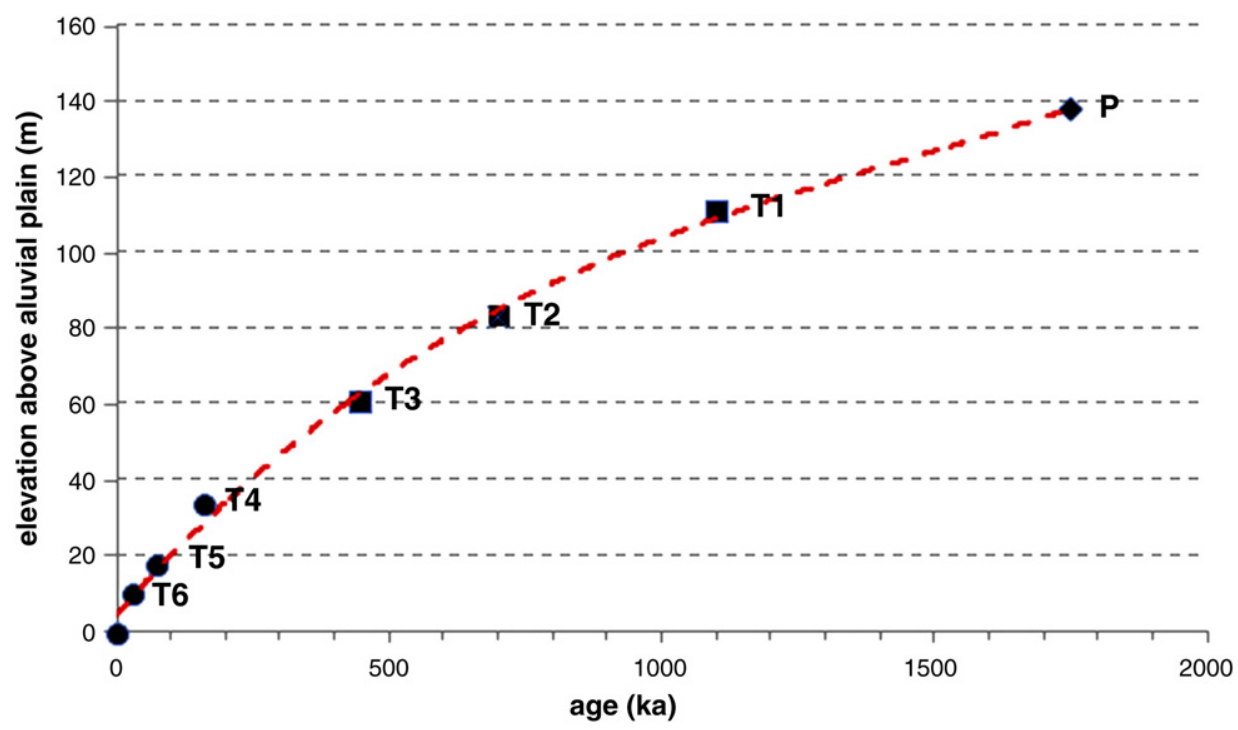

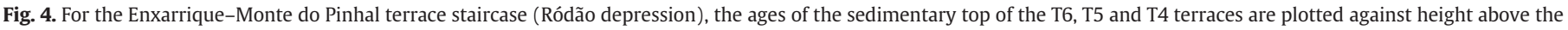

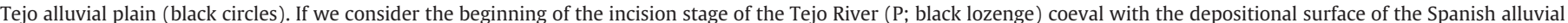

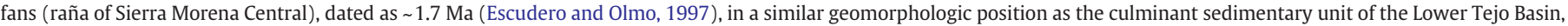

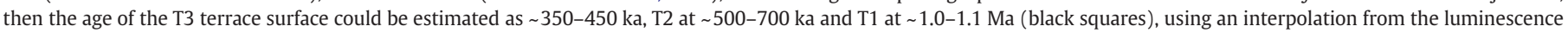
ages of the younger terraces. 


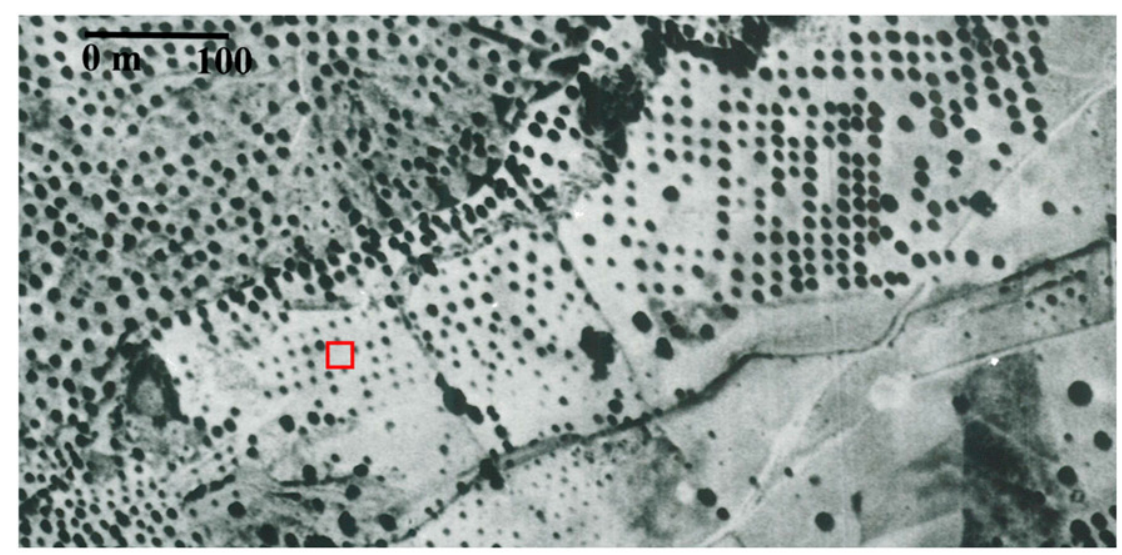

37

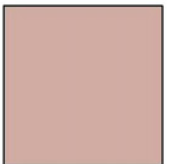

38

39

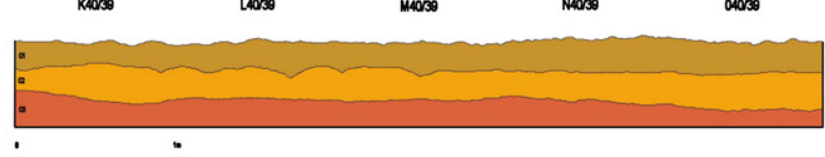

40

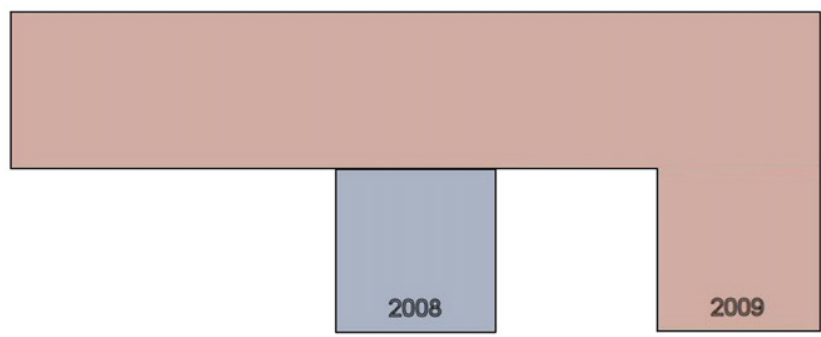

ᄂ

$\mathbb{M}$

$\mathbf{N}$

(3)
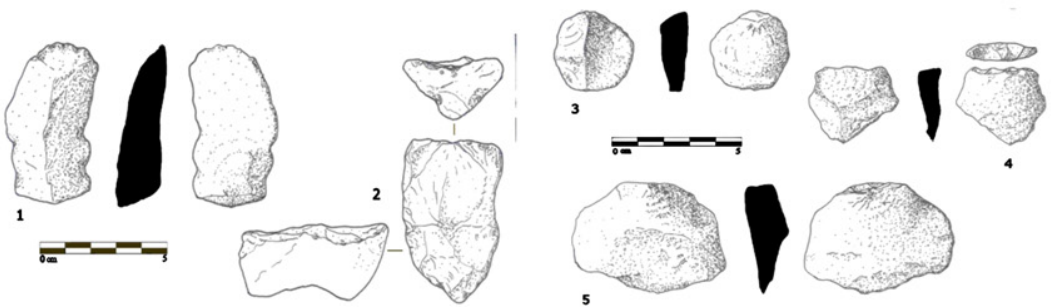

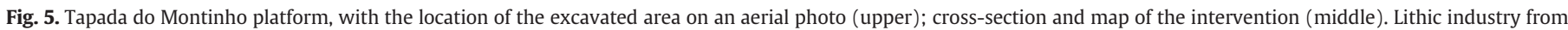

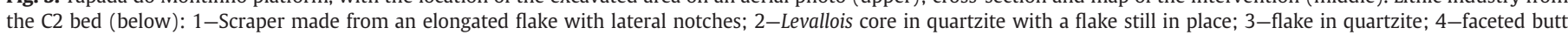
flakes; 5-Kombewa flake. The excavated squares refer to a local system of coordinates: X (K, L, M and O); Y (37, 38, 39, 40 and 41).

the Tejo course was superimposed onto the hanging wall of the Ponsul fault thrust, and continued the exhumation of the fault scarp from beneath the Tertiary sandstones. At that time, the Nisa stream had its mouth near its present-day confluence with the Tejo River (no terrace deposits were found at the T3 level between the present Nisa stream and the Arneiro depression). The N3 level in the Arneiro depression was presumably created by headwater erosion of the Vale stream into the weaker Palaeogene sandstones.

During the final incision stage, the Tejo River produced a narrow valley downstream of the Ponsul fault and the lower terraces at the mouth of the Vale stream (respectively T4 at $121 \mathrm{~m}, \mathrm{~T} 5$ at $90 \mathrm{~m}$ and $\mathrm{T} 6$ at $82 \mathrm{~m}$ of altitude a.s.l.).

\section{Archaeological study of the new sites}

\subsection{The Tapada do Montinho site}

The Palaeolithic site named Tapada do Montinho (geographical coordinates: $39^{\circ} 37^{\prime} 44^{\prime \prime} ;-7^{\circ} 41^{\prime} 27^{\prime \prime} ; 125$ m a.s.l.; Figs. 3 and 5), discovered in 2003 , is located on the top of an alluvial platform delimited by two small streams. A large amount of knapped quartzite material, some flint and some quartz, was found here over an area of $25,000 \mathrm{~m}^{2}$ (Almeida et al., 2008).

In 2008, an excavation was carried out in order to verify the existence of Palaeolithic artefacts in situ. The site was divided in three 


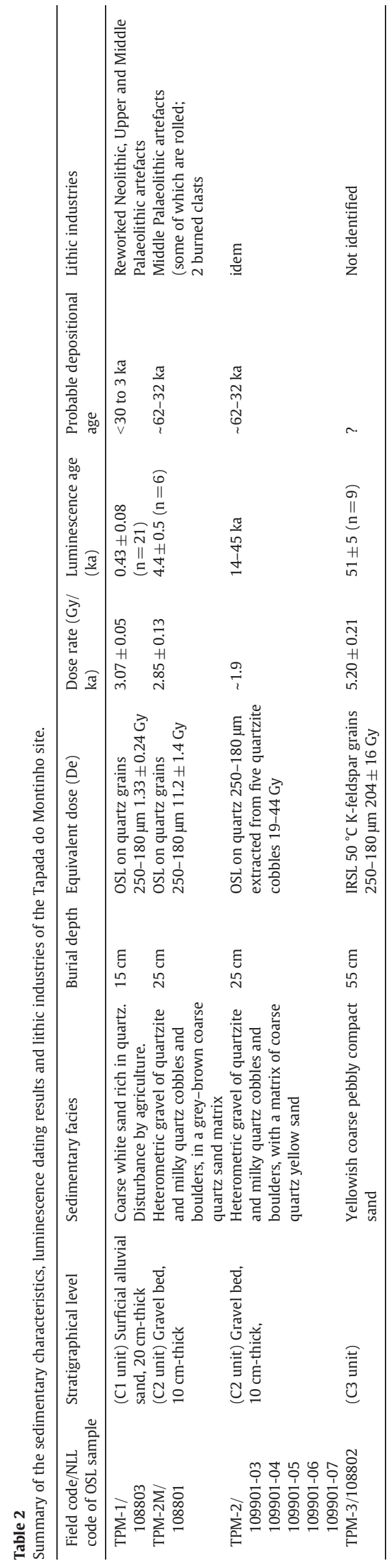

sectors. Four survey pits of $1 \mathrm{~m}^{2}$ were excavated in the first and second sectors (Fig. 5). A layer with well-preserved in situ Middle Palaeolithic industry was found. The spatial distribution and distance of refitted tool-stones (a technique that involves reconstructing the sequence of flake removal during the knapping activity), confirms that the archaeological materials suffered no or little disturbance after the discard by prehistoric human groups.

In 2009, a second campaign was undertaken with the objective of enlarging the excavated area and sampling for luminescence dating. Stratigraphic, sedimentary and archaeological records were described and studied in detail.

The topmost sedimentary unit (C1), $20 \mathrm{~cm}$ thick, is composed of coarse sand, mainly of quartz, with some organic material (Table 2). Some lithic remains were recovered and on the basis of their morphological and typological analysis, were assigned to the Neolithic, Upper Palaeolithic and Middle Palaeolithic. The depositional age of the $\mathrm{C} 1$ unit is not available because the quartz OSL values obtained from the sediment sample were unexpectedly small and highly scattered, probably due to reworking by recent agricultural activity.

Unit C2, 10-15 cm-thick, is a gravelly bed with angular to subrounded quartzite cobbles in a pebbly sandy grey-brown matrix. It contains a rich industry $\left(\sim 100\right.$ pieces $\left./ \mathrm{m}^{2}\right)$, providing an older Levallois edge and surface rounded flake industry (that were transported from a nearby location), and a more recent industry, characterised by fresh, opportunistic pebble edge knapping, indigenous to its geological context. Detailed observation of this collection allows the identification of two refitting sequences and a case of three elongated flakes that do not refit but, due to the colour and texture of the raw material, probably come from the same knapping sequence. In these three cases, two refitting sequences come from flakes registered in the same square metre (L40 square, flakes 75 and 144; M40 square: flakes 4, 40 and 59). The other refitting was found between two fragments of the same flake that were located $5 \mathrm{~m}$ apart (quadrants N37 and M41). In this case, one of the fragments presents some macroscopic evidence for usage from wear marks. In the rounded Levallois industry no refittings were achieved. The industry used quartzite $(82 \%)$, flint (11\%) and quartz (6\%); the quality of the local fine-grained quartzite explaining the predominance of this raw material in the assemblage. The quality of the quartzite is sufficient to allow the application of Levallois knapping reduction and this has also been detected at other Portuguese sites, such as the Oliveira cave (at the Estremenho Massif) (Marks et al., 2001; Zilhão, 2006). Quartzite is also the preferred raw material in the nearby Middle Palaeolithic sites of Vilas Ruivas and Foz do Enxarique (Raposo, 1995a). In the lithic industry (Fig. 5), we identified cores, Kombewa flakes, some faceted-butt flakes and scrapers, some with lateral notches (probably for hafting). Levallois flakes are also present.

Technologically, the $\mathrm{C} 2$ assemblage can be assigned to two different phases of the Middle Palaeolithic. The older rounded Levallois industry is characterised by scrapers made from bigger flakes. The more recent Middle Palaeolithic industry is characterised by small products; this industry is obtained from an opportunistic pebbleedge knapping of the core. The analysis of the refitting pieces and of the remainder of the collection has resulted in the identification of two types of knapping strategy. The objective of the first was to obtain short but very large flakes, whereas the second aimed for elongated flakes. The Kombewa flakes recovered from the Tapada do Montinho site have bigger dimensions than the rest of the flakes and cores in the assemblage. This could mean that they were already knapped when brought to the site. Two burned clasts were also found, suggesting the existence of a campfire.

Luminescence dating based on rock slices (Sohbati et al., 2012) suggest that one cobble surface, and the inner parts of two other 


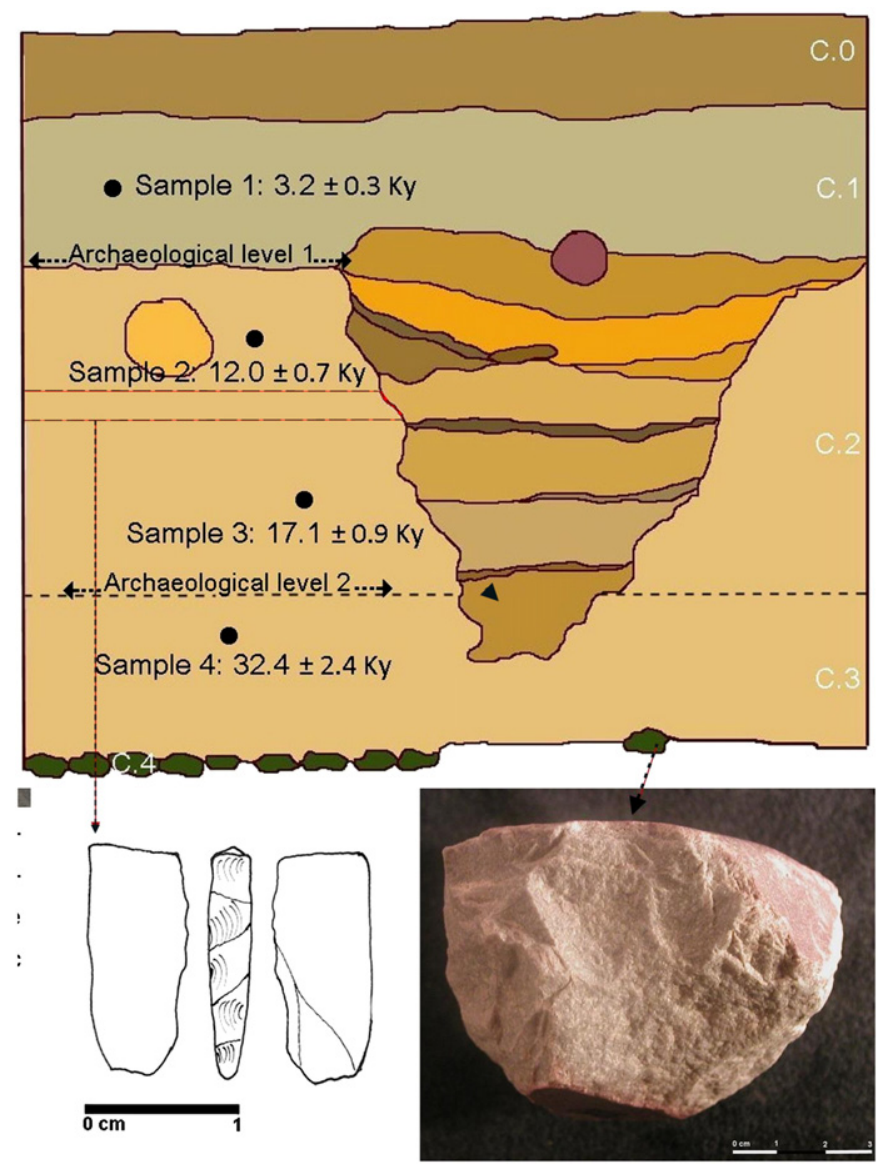

Fig. 6. Stratigraphic section at Castelejo (C.0, C.1, C.2, C.3 and C.4 are the labels for the five stratigraphic layers), with the location of the four OSL samples, the two archaeological levels, the cobble pavement, the fragment of an Upper Palaeolithic backed bladelet (lower left; collected from a level in the upper part of the C.2 layer) and the Middle Palaeolithic core found during the excavation (lower right).

cobbles experienced a resetting event at $\sim 45 \mathrm{ka}$ (the probable burial age), consistent with the minimum age of $\sim 32$ ka expected for the Mousterian industry in this region. However, the surfaces of the other cobbles all record light exposure events in the range 26 to $14 \mathrm{ka}$, suggesting that some of the cobbles were exposed to daylight perhaps more than once in this period. The younger age obtained for the sandy matrix could also result from exposure to daylight after deposition, possibly by agricultural activity (the layer is only $35 \mathrm{~cm}$ from the present day surface).

The $\mathrm{C} 3 \mathrm{bed},>20 \mathrm{~cm}$ thick, consists of a yellowish coarse sand with small rolled pebbles and is archaeologically sterile. Luminescence dating provided an age of $51 \pm 5 \mathrm{ka}$ (K-feldspar IRSL signal at $50{ }^{\circ} \mathrm{C}$ ).

\subsection{The Castelejo site}

The Castelejo site is located close to the Tejo River (geographical coordinates: 39³8' 270 15"; - $7^{\circ} 41^{\prime} 22 " ; 121 \mathrm{~m}$ ) (Figs. 2 and 3) and corresponds to a remnant of the T4 terrace, with a $1 \mathrm{~m}$-thick cover of aeolian sands. It is located in the central area of a Roman gold mine covering $\sim \mathrm{km}^{2}$, which involved the processing of roughly $1060 \mathrm{~m}^{3}$ of the T4 terrace (Deprez et al., 2009). The piles of boulders (spoil), left by the Romans in this type of exploitation, is known in the region as "Conhal".

A survey pit $\left(1 \mathrm{~m}^{2}\right)$ was opened in the centre of the uppermost level of the Castelejo site (Fig. 6) and four samples for OSL dating were taken (Table 3 ). The $20 \mathrm{~cm}$-thick uppermost bed (Bed CO; Fig. 6), comprises fine aeolian quartz sand with organic material, and shows evidence of agricultural activity. The bed $\mathrm{C} 1,10 \mathrm{~cm}-$ thick, consists of fine aeolian sand in which the OSL sample CAST1 $(3.2 \pm 0.2 \mathrm{ka})$ was collected. Some recent Prehistoric artefacts were found in this deposit, including a manual millstone and ceramics. The bed $\mathrm{C} 2, \sim 40 \mathrm{~cm}$ thick, consists of fine aeolian sand in which the OSL samples CAST2 $(12.0 \pm 0.7 \mathrm{ka})$ and CAST3 $(17.1 \pm 0.9 \mathrm{ka})$ were collected from the top and base, between the archaeological levels AL1 and AL2. The techno-typological analysis of the industry from these two archaeological levels was inconclusive, due to the limited number of pieces found. One fragment of a bladelet, a typical Upper Palaeolithic tool, was found in layer C2 (Fig. 6), located between the OSL samples CAST2 and CAST3. The $\sim 20 \mathrm{~cm}$ thick bed $\mathrm{C} 3$ consists of fine aeolian sand, from which the OSL sample CAST4 $(32.4 \pm 2.4 \mathrm{ka})$ was collected. The bed C4 is a conglomeratic pavement of rounded cobbles, from which a Middle Palaeolithic core was collected.

The bed C5 corresponds with the deposits of the T4 terrace, here reaching a thickness of $12 \mathrm{~m}$ and comprising reddish cobble to boulder gravels $(M P S=40 \mathrm{~cm}$ ). The base is a disconformity (at $109 \mathrm{~m}$ a.s.l.) developed into Palaeogene sandstone bedrock.

\section{Discussion}

In the Lower Tejo, the dated Lower, Middle and Upper Palaeolithic open air occupations and their associated sedimentary contexts, represent advances in the knowledge about these periods in the Iberian Peninsula. When a better chronostratigraphic framework is available

Table 3

Summary of the sedimentary characteristics, luminescence dating results (OSL on 250-180 $\mu \mathrm{m}$ quartz grains) and lithic industries of the Castelejo site.

\begin{tabular}{|c|c|c|c|c|c|c|c|c|}
\hline $\begin{array}{l}\text { Field code/NLL code } \\
\text { of OSL sample }\end{array}$ & Stratigraphical level & Sedimentary facies & $\begin{array}{l}\text { Burial depth } \\
(\mathrm{cm})\end{array}$ & Dose (Gy) & $\begin{array}{l}\text { Dose rate } \\
(\mathrm{Gy} / \mathrm{ka})\end{array}$ & $\begin{array}{l}\text { Lumin. } \\
\text { age (ka) }\end{array}$ & $\begin{array}{l}\text { Probable } \\
\text { age (ka) }\end{array}$ & Lithic industries \\
\hline- & $\begin{array}{l}\text { C0 bed surficial aeolian sand with } \\
\text { organic matter, } 20 \mathrm{~cm} \text {-thick }\end{array}$ & $\begin{array}{l}\text { Fine white quartz sand. } \\
\text { Disturbance by agricultural works. }\end{array}$ & - & - & - & - & - & - \\
\hline \multirow[t]{2}{*}{ CAST1 PC5226 } & $\mathrm{C} 1$ bed aeolian sand, $10 \mathrm{~cm}$-thick & Fine white quartz sand. & 20 & $\begin{array}{l}16.3 \pm 1.0 \\
(\mathrm{n}=24)\end{array}$ & $\begin{array}{l}5.08 \\
\pm 0.23\end{array}$ & $\begin{array}{l}3.2 \\
\pm 0.2\end{array}$ & & $\begin{array}{l}\text { Neolithic artefacts } \\
\text { and ceramics }\end{array}$ \\
\hline & C2 bed uppermost part & Archaeological level AL1 & & & & & 12 & \\
\hline CAST2 PC5227 & $\mathrm{C} 2$ bed aeolian sand, $10 \mathrm{~cm}$-thick & Fine white quartz sand & 35 & $\begin{array}{l}60 \pm 2 \\
(n=27)\end{array}$ & $\begin{array}{l}5.01 \\
\pm 0.22\end{array}$ & $\begin{array}{l}12.0 \\
\pm 0.7\end{array}$ & & Upper Palaeolithic \\
\hline \multirow[t]{2}{*}{ CAST3 PC5228 } & $\mathrm{C} 2$ bed aeolian sand, $10 \mathrm{~cm}$-thick & Fine white quartz sand. & 50 & $\begin{array}{l}86 \pm 2 \\
(n=24)\end{array}$ & $\begin{array}{l}5.03 \\
\pm 0.22\end{array}$ & $\begin{array}{l}17.1 \\
\pm 0.9\end{array}$ & & \\
\hline & C2 bed (lowermost part) & Archaeological level AL2 & & & & & $18-28$ & \\
\hline \multirow[t]{3}{*}{ CAST4 PC5229 } & C3 bed Aeolian sand, $20 \mathrm{~cm}$-thick & Fine white quartz sand & 75 & $\begin{array}{l}161 \pm 9 \\
(n=24)\end{array}$ & $\begin{array}{l}4.95 \\
\pm 0.22\end{array}$ & $\begin{array}{l}32.4 \\
\pm 2.4 \mathrm{ka}\end{array}$ & & \\
\hline & C4 bed, $\sim 5 \mathrm{~cm}$-thick & $\begin{array}{l}\text { Pavement of rounded cobles and } \\
\text { some artefacts }\end{array}$ & & & & & $\sim 60-30$ & $\begin{array}{l}\text { Middle } \\
\text { Palaeolithic }\end{array}$ \\
\hline & C5 bed, T4 terrace, $\sim 14$ m-thick & $\begin{array}{l}\text { Reddish very coarse sands and } \\
\text { cobble to boulder gravels }\end{array}$ & & & & & $>140$ & - \\
\hline
\end{tabular}


Table 4

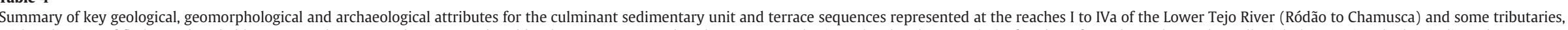
with indication of flights and probable ages. Local terrace codes were replaced by the ones recognised at the Lower Tejo basin scale. The elevation ( $\mathrm{m}$ ) of each surface, above the modern alluvial plain or river bed, is indicated.

\begin{tabular}{|c|c|c|c|c|}
\hline $\begin{array}{l}\text { Cunha et al. (2008) } \\
\text { Ródão depression } \\
\text { Lower Tejo reach I }\end{array}$ & $\begin{array}{l}\text { (This work) } \\
\text { Arneiro depression } \\
\text { Lower Tejo reach I }\end{array}$ & $\begin{array}{l}\text { Martins et al. (2009) } \\
\text { Gavião-Chamusca area } \\
\text { Lower Tejo reaches III-IVa }\end{array}$ & $\begin{array}{l}\text { Martins et al. (2010a, 2010b) } \\
\text { V.N.B. - Sta. Cita area Ponte } \\
\text { da Pedra stream and Bezelga-Nabão system }\end{array}$ & $\begin{array}{l}\text { Summary of the lithic industries in the reaches I-IV of } \\
\text { the lower Tejo basin }\end{array}$ \\
\hline $\begin{array}{l}\text { Falagueira formation }(\mathrm{P}) \text { not dated } \\
\quad \text { (Pliocene-Lower Pleistocene?) } \\
\quad+138 \mathrm{~m} \text { ? }\end{array}$ & $\begin{array}{l}\text { Falagueira formation }(\mathrm{P}) \text { not dated } \\
\text { (upper Pliocene-Lower Pleistocene?) } \\
+218 \mathrm{~m} \text { ? }\end{array}$ & $\begin{array}{l}\text { Almeirim and Ulme formations not dated } \\
\text { (Pliocene to Lower Pleistocene?) } \\
+174-210 \mathrm{~m}\end{array}$ & $\begin{array}{l}\text { Almeirim formation not dated } \\
\text { (Pliocene to Lower Pleistocene?) } \\
+162 \mathrm{~m}\end{array}$ & Not found \\
\hline $\begin{array}{l}\text { Monte do Pinhal terrace (T1) not dated } \\
\text { (Pleistocene) } \\
\quad+111 \mathrm{~m}\end{array}$ & $\begin{array}{l}\text { Alluvial fan and rocky terrace on the } \\
\text { quartzites of the Portas do Ródão gorge } \\
\text { (N1) } \\
+153 \mathrm{~m}\end{array}$ & $\begin{array}{l}\text { Terrace } \mathrm{T} 1 \text { not dated } \\
\text { (Pleistocene) } \\
+84-164 \mathrm{~m}\end{array}$ & $\begin{array}{l}\text { Terrace T1 not dated } \\
\text { (Lower-Middle Pleistocene?) } \\
+124 \mathrm{~m}\end{array}$ & Not found \\
\hline $\begin{array}{l}\text { Monte da Charneca upper terrace (T2) } \\
\text { not dated } \\
\text { (Pleistocene) } \\
\quad+83 \mathrm{~m}\end{array}$ & $\begin{array}{l}\mathrm{N} 2 \text { erosive surface and the } \mathrm{T} 2 \text { terrace } \\
+108 \mathrm{~m}\end{array}$ & $\begin{array}{l}\text { Terrace } \mathrm{T} 2 \text { not dated } \\
\text { (Pleistocene) } \\
+57-112 \mathrm{~m}\end{array}$ & $\begin{array}{l}\text { Terrace T2 not dated } \\
\text { (Middle Pleistocene) } \\
+92 \mathrm{~m}\end{array}$ & Not found \\
\hline $\begin{array}{l}\text { Monte da Charneca upper terrace (T3) } \\
\text { not dated (Pleistocene) } \\
+61 \mathrm{~m}\end{array}$ & $\begin{array}{l}\text { N3 erosive surface and the } \mathrm{T} 3 \text { terrace } \\
+78 \mathrm{~m}\end{array}$ & $\begin{array}{l}\text { Pego terrace (T3) (minimal ages) } \\
\text { (Middle Pleistocene) } \\
+43-73 \mathrm{~m}\end{array}$ & $\begin{array}{l}\text { Terrace T3 (minimal ages) } \\
\text { (Middle Pleistocene) } \\
+57 \mathrm{~m}\end{array}$ & Not found \\
\hline $\begin{array}{l}\text { Monte do Famaco terrace (T4) the top } \\
\text { is }>135 \mathrm{ka} \text { (probably } 160 \mathrm{ka}) \text {; the base } \\
\text { is }>280 \mathrm{ka} \text { (probably } 340 \mathrm{ka} \text { ); } \\
\text { (late Middle Pleistocene) } \\
+34 \mathrm{~m}\end{array}$ & $\begin{array}{l}\text { Arneiro terrace (T4) the top is }>135 \mathrm{ka} \\
\text { (probably } 160 \mathrm{ka} \text { ); the base is }>280 \mathrm{ka} \\
\text { (probably } 340 \mathrm{ka} \text { ); } \\
\text { (late Middle Pleistocene) } \\
+48 \mathrm{~m}\end{array}$ & $\begin{array}{l}\text { Atalaia terrace (T4) }>220 \text { to } \sim 160 \mathrm{ka} \\
\text { (late Middle Pleistoc.) } \\
+26-63 \mathrm{~m}\end{array}$ & $\begin{array}{l}\text { Atalaia terrace }(\mathrm{T} 4)>190 \\
\text { to } 160 \mathrm{ka} \\
\text { (late Middle Pleistoc.) } \\
+37 \mathrm{~m}\end{array}$ & $\begin{array}{l}\text { Lower Palaeolithic (lower-late Acheulian) Monte } \\
\text { Famaco, Vale do Forno, Fonte da Moita, Rib. Ponte da } \\
\text { Pedra-early Middle Palaeolithic at the topmost; Pegos } \\
\text { do Tejo, Vale do Forno } 8\end{array}$ \\
\hline $\begin{array}{l}\text { Sra. da Alagada terrace (T5) } 135 \text { to } 73 \mathrm{ka} \\
\text { (Upper Pleistocene) } \\
\quad+18 \mathrm{~m}\end{array}$ & $\begin{array}{l}\text { T5 at }+18 \mathrm{~m} \text {; alluvial sediments at } \\
\text { Tapada do Montinho ( } 78 \mathrm{ka}) \text {; fluvial } \\
\text { record at Vilas Ruivas (palaeo-tributary; } \\
113 \text { to } 105 \mathrm{ka} \text { ) }\end{array}$ & $\begin{array}{l}\text { Entroncamento terrace }(\mathrm{T} 5) \sim 125 \\
\text { to } 76 \mathrm{ka} \\
\text { (Upper Pleistocene) } \\
+18-28 \mathrm{~m}\end{array}$ & $\begin{array}{l}\text { Entroncamento terrace } \\
\text { (T5) } \sim 125 \text { to } 90 \mathrm{ka} \\
\text { (Upper Pleistocene) } \\
+16 \mathrm{~m}\end{array}$ & $\begin{array}{l}\text { Middle Palaeolithic (Mousterian) Sra. Alagada chapel, } \\
\text { Vilas Ruivas silt bed, Rib. Ponte da Pedra, Sto. Antão do } \\
\text { Tojal }\end{array}$ \\
\hline $\begin{array}{l}\text { Foz do Enxarrique terrace (T6) } 39 \text { to } 32 \mathrm{ka} \\
\text { (uppermost Pleist.) } \\
\quad+10 \mathrm{~m}\end{array}$ & $\begin{array}{l}\text { T6 terrace (62 to } 32 \mathrm{ka} \text { ) at }+10 \mathrm{~m} \text { and } \\
\text { alluvial sediments (Tapada do Montinho) } \\
\text { (uppermost Pleist.) }\end{array}$ & $\begin{array}{l}\text { Golegã terrace (T6) } 55 \text { to } 51 \mathrm{ka} \\
\text { (uppermost Pleistoc.) } \\
+0-10 \mathrm{~m}\end{array}$ & $\begin{array}{l}\text { Golegã terrace }(\mathrm{T} 6) \sim 62 \\
\text { to } \sim 30 \text { ka (uppermost Pleist.) } \\
+7 \mathrm{~m}\end{array}$ & $\begin{array}{l}\text { Late Middle Palaeolithic (late Mousterian) Foz } \\
\text { Enxarique, Tapada do Montinho, Conceição, Santa Cita }\end{array}$ \\
\hline $\begin{array}{l}\text { Colluvium and aeolian sands (these not } \\
\text { preserved); } \\
\text { (uppermost Pleistocene) }\end{array}$ & $\begin{array}{l}\text { Colluvium and aeolian sands } 32 \text { to } 12 \mathrm{ka} \text {; } \\
\text { (uppermost Pleistocene) }\end{array}$ & $\begin{array}{l}\text { Colluvium and Carregueira Sands } \\
\text { (aeolian sands climbing on the SE slopes) } \\
\text { (uppermost Pleistoc.) }\end{array}$ & $\begin{array}{l}\text { Colluvium and fine-grained } \\
\text { aeolian sands deposited on } \\
\text { the valley slopes } \sim 30 \text { to ?12 ka; } \\
\text { (uppermost Pleistoc.) }\end{array}$ & $\begin{array}{l}\text { Upper Palaeolithic to Epipalaeolithic Tapada do } \\
\text { Montinho Rib. Ponte da Pedra, Santa Cita }\end{array}$ \\
\hline $\begin{array}{l}\text { Valley fill deposits underlying the present } \\
\text { floodplain } \\
+2 \mathrm{~m} \text { (Holocene) }\end{array}$ & $\begin{array}{l}\text { Valley fill deposits and local aeolian } \\
\text { sands }(\sim 4-0 \mathrm{ka}) \\
\text { (Holocene) }\end{array}$ & $\begin{array}{l}\text { Valley fill deposits underlying the } \\
\text { present floodplain } \\
\text { (Holocene) }\end{array}$ & $\begin{array}{l}\text { Valley fill deposits and local } \\
\text { aeolian dunes rising above the } \\
\text { alluvial plain; } \sim 12-0 \text { ka; } \\
\text { (uppermost Pleistoc. to Holocene) }\end{array}$ & $\begin{array}{l}\text { Mesolithic and more recent industries } \\
\text { (several sites) }\end{array}$ \\
\hline
\end{tabular}


for all of Europe, the comparison of the Portuguese Tejo River records with records of fluvial evolution and human occupation and migration in Spain (e.g. Santisteban and Schulte, 2007) and nearby European systems (Bridgland et al., 2006, 2007; Westaway et al., 2009) will be very important.

In the Ródão and Arneiro depressions, and in the downstream reaches of the Lower Tejo River, the T4 terrace contains Lower Palaeolithic industries (supposedly lower to late Acheulian; see also Oosterbeck et al., 2010; Table 4). In the Lower Tejo River, Middle Palaeolithic industries were identified in the topmost part of T4 (replacing the Acheulian industries probably at $~ 160 \mathrm{ka}$ ), but also associated with T5 (Vilas Ruivas and Sto. Antão do Tojal sites) and T6 (Foz do Enxarrique and Conceição sites) (Raposo, 1986, 2000, 2002).

The Middle Palaeolithic industries represent a change, both with respect to occupation patterns and typological characterization of the industry. Fairly complex living structures (fireplaces with wind screens, etc.) were constructed (e.g. at Vilas Ruivas) and the Levallois method was used widely, with an almost complete abandonment of previous large instruments (hand axes, cleavers, scrapers, etc.).

The Upper Palaeolithic is not well documented in Reach I of the Lower Tejo (Table 4). The artefacts that have been discovered so far in river terrace deposits cannot be clearly linked to the initial phases of this cultural period. Due to this, studies in the aeolian sand deposits (supposedly bracketing the Upper Palaeolithic) are important and should be further developed in future work in conjunction with OSL dating to provide an accurate age control.

In the western Iberia offshore region, during the period 57 to $31 \mathrm{ka}$, climate was characterised by a succession of mild and wet periods (interstadials) alternating with cold and dry periods (stadials), related to the Dansgaard-Oescheger (D-O) cycles (Lebreiro et al., 1996; De Abreu et al., 2003; Roucoux et al., 2005). A succession of D-O cycles also occurred after $31 \mathrm{ka}$; however, in the 57 to $31 \mathrm{ka}$ period ten $\mathrm{D}-\mathrm{O}$ insterstadials occurred, while in the last 31 ka only four occurred. The Lower Tejo T6 terrace, poor in clay matrix and ranging in age $\sim 62$ to $32 \mathrm{ka}$, is the sedimentary record located onshore of these mild-cold and wet climate conditions.

The climate conditions were particularly severe during the Heinrich events (He) (Heinrich, 1988), of which there were three after $31 \mathrm{ka}$ at $30.2-29.0 \mathrm{ka}$ (He3), 24.3-23.1 ka (He2) and 17.6-14.9 ka (He1) (Lebreiro et al., 1996). Pollen data indicate a dominance of open herbaceous vegetation, with increased areas of steppe in the period 31-23 ka (Roucoux et al., 2005). In the western part of Iberia, the mean temperature of the coldest month could have ranged between $0{ }^{\circ} \mathrm{C}$ and $-6{ }^{\circ} \mathrm{C}$ during the Heinrich events (He), from $-2{ }^{\circ} \mathrm{C}$ to $2{ }^{\circ} \mathrm{C}$ during the $\mathrm{D}-\mathrm{O}$ stadials, whilst it is $5^{\circ} \mathrm{C}$ in the present day (Sánchez Goñi et al., 2002). The annual rainfall values could have reached $400 \mathrm{~mm}$ during the Heinrich events; $500 \mathrm{~mm}$ in the D-O stadials, while in the present day are $800 \mathrm{~mm}$ (Sánchez Goñi et al., 2002). In the study area and adjacent reaches of the Lower Tejo valley, these cold-dry climate conditions would have modified the flow regime of the river, with limited fluvial sediment transport and low flow conditions. This is most marked when a change from fluvial to aeolian sedimentation occurred at $\sim 32 \mathrm{ka}$. This environmental change coincides with the disappearance of the Megafauna and associated Neanderthal communities, as well as the replacement of the Middle Palaeolithic industries by Upper Palaeolithic ones. This relationship between environmental change and alterations to early human occupation and industry styles agrees with dated sedimentary records in other areas of Portugal (Raposo, 2000; Aubry et al., 2011).

The aeolian sands began to be carried from the exposed alluvial plain, by NW winds, just after the time when the Tejo River started to cut down, at $32 \mathrm{ka}$. The OSL ages of the aeolian sand unit indicates two main phases of aeolian activity:

i) one from 32 to $12 \mathrm{ka}$, containing Upper Palaeolithic industries and corresponding to the last Pleniglacial (28-13.5 ka); this coincides with the onset of a severe cold and dry climate in the North Atlantic (Roucoux et al., 2005);

(ii) a later phase at $\sim 3 \mathrm{ka}$ (only one date); this agrees with the "Cold period 1", dated 1000 to 250 yr cal BC (Sánchez Goñi, 2006), with the colder climate conditions during the Iron Age Epoch (900 to $300 \mathrm{yr}$ BC) recorded in northeastern Spain (GutiérrezElorza and Peña-Monné, 1998), or with the classical SubBoreal climatic period (temperate dry conditions; 5 to $2 \mathrm{ka}$ ).

During 32 to $12 \mathrm{ka}$, the offshore climate conditions were more severe (colder and drier) than in the period 57 to $32 \mathrm{ka}$. This could explain why the coeval archaeological remains were found mainly in caves and are rare in fluvial and aeolian sedimentary deposits. The Arneiro depression probably gave some sheltered conditions against the strong and cold winds but also provided resources associated to the Tejo River (food, water and raw materials).

\section{Conclusions}

This study, focused on the Arneiro depression, provides a geomorphological characterization and interpretation of the landscape evolution of the River Tejo in its most upstream Portuguese reach. It has enabled an improved understanding of the chronology of the three lower terraces and also provides some constraint for the ages of the upper terrace surfaces, for which absolute dating was previously unavailable:

Terrace T1-top at $\sim 1.0-1.1 \mathrm{Ma}$

Terrace T2-top at $\sim 500-700 \mathrm{ka}$

Terrace T3-top at $\sim 350-450 \mathrm{ka}$

Terrace T4- 340 to $\sim 160 \mathrm{ka}$

Terrace T5-136 to $75 \mathrm{ka}$

Terrace T6-62 to $32 \mathrm{ka}$.

In Reaches I-IV of the Lower Tejo, the oldest artefacts were found in the T4 terrace base. This indicates that the probable age for the oldest human occupation found so far in Portugal is ca. $340 \mathrm{ka}$.

New data have been collected in the Tapada do Montinho and Castelejo sites, containing Middle Palaeolithic to Upper Palaeolithic industries preserved in situ on the dated sedimentary successions. These data provide new insights into the geomorphological context, sedimentary forcing and chronology associated with human occupation during the Late Pleistocene in western Iberia. More specifically, the research provides new data concerning human activity in this area under the cold climate conditions of the last 62 to $12 \mathrm{ka}$, including the very dry conditions from 32 to $12 \mathrm{ka}$; the latter period has important implications for aeolian dynamics within river valley settings.

Absolute dating was provided by luminescence methods, using sedimentary quartz and K-feldspar (the latter was the only available method when the quartz OSL signal reached saturation) and the rock surface of quartzite cobbles. The OSL dating from surface cobbles is a promising method for dating geological and archaeological materials.

Integration of the available archaeological data indicate that Acheulian industries (Lower Palaeolithic) were replaced by the Middle Palaeolithic ones at $\sim 160 \mathrm{ka}$, and that these in turn were replaced by Upper Palaeolithic industries at $32 \mathrm{ka}$; the coeval marked environmental changes could be responsible for the disappearance of the Megafauna and associated Neanderthal communities. This work also provides the first identification of dated Upper Palaeolithic industries in this upstream reach of the Lower Tejo River. The relationship of the Upper Palaeolithic industries with aeolian sediments demonstrates some presence of human activity in valley floor floodplain areas (possibly more sheltered locations) and a period when the climate was cold and dry. Normally, evidence for human 
activity during this time period appears to be associated with cave sites that are fully protected from prevailing winds.

\section{Acknowledgements}

This work is part of the activities of the projects PHANA and PTDC/ CTE-GIN/66283/2006, approved by the Fundação para a Ciência e a Tecnologia and co-founded by the FEDER. The Nisa town hall is thanked for the financial support to the archaeological excavation (N. Almeida) and OSL dating. Research also has been supported by the IMAR-CMA Univ. Coimbra, Centro de Geofísica - Univ. Évora (Portugal), and both Aarhus University and Risø DTU (Denmark). Martin Stokes (Univ. Plymouth), D.R. Bridgland (Durham University) and an anonymous reviewer are thanked for their very thorough and constructive reviews.

\section{References}

Almeida, N., Deprez, S., De Dapper, M., 2008. The Palaeolithic occupation of the Northeastern of Alen Tagus (Portugal): a geoarchaeological approach. In: BuenoRamirez, P., Barroso-Bermejo, R., Balbín Berhmann, R. (Eds.), Graphical Markers and Megalith Builders in the International Tagus, Iberian Peninsula: British Archaeological Reports International Series, 1765, pp. 19-26.

Aubry, T., Bicho, N.F., 2006. Le Paléolithique supérieur du Portugal. In: Noiret, P. (Ed.), Le Paléolithique supérieur européen. Bilan quinquennal 2001-2006. UISPP, Liège, pp. 135-145 (ERAUL 115).

Aubry, T., Mangado Llach, X., Sellami, F., Sampaio, J.D., 2002. Open-air Rock-art. Territories and modes of exploitation during the Upper Paleolithic in the Côa Valley (Portugal). Antiquity 76 (291), 62-76.

Aubry, T., Almeida, M., Dimuccio, L., Gameiro, C., Neves, M.-J., Klaric, L., 2008. Caractérisation et discontinuités des registres pédo-sédimentaires de l'occident péninsulaire entre 30.000 et 10.000 BP. In: Aubry, T., Almeida, F., Cristina Araújo, A., Tiffagom, M. (Eds.), BAR S1831 2008: Proceedings of the XV World Congress UISPP (Lisbon, 4-9 September 2006), Vol. 21, pp. 9-21. Sessions C64 and C65,.

Aubry, T., Dimuccio, L., Mercè, Bergadà M., Sampaio, J.D., Sellami, F., 2010. Palaeolithic engravings and sedimentary environments in the Côa River Valley (Portugal): implications for the detection, interpretation and dating of open-air rock art. Journal of Archaeological Science 37, 3306-3319.

Aubry, T., Dimuccio, L.A., Almeida, M., Neves, M.J., Angelucci, D., Cunha, L., 2011 Palaeoenvironmental forcing during the Middle-Upper Palaeolithic transition in Central-western Portugal. Quaternary Research 75, 66-79.

Benito Calvo, A., Pérez-González, A., Santonja, M., 1998. Terrazas rocosas, aluviales y travertínicas del valle alto del río Henares (Guadalajara, España). Geogaceta 24, $55-58$.

Benito, G., Sopeña, A., Sánchez-Moya, Y., Machado, M.J., Pérez-González, A., 2003. Palaeoflood record of the Tagus River (Central Spain) during the Late Pleistocene and Holocene. Quaternary Science Reviews 22, 1737-1756.

Bridgland, D., Antoine, P., Limondin-Lozouet, N., Santisteban, J., Westaway, R., White, M., 2006. The Palaeolithic occupation of Europe as revealed by evidence from the rivers: data from IGCP 449. Journal of Quaternary Science 21, 437-455.

Bridgland, D.R., Keen, D.H., Westaway, R., 2007. Global correlation of Late Cenozoic fluvial deposits: a synthesis of data from IGCP 449. Quaternary Science Reviews 26 2694-2700.

Brugal, J., Raposo, L., 1999. The role of the Early Humans in the accumulation of European Lower and Middle Palaeolithic bone assemblages. Monographien des Römisch-Germanischen Zentralmuseums 42, 367-378.

Cardoso, J.L., 1993. Contribuição para o conhecimento dos grandes mamíferos do Plistocénico Superior de Portugal. Camara Municipal de Oeiras, Oeiras. 567 pp.

Cunha, P.P., 1996. Unidades litostratigráficas do Terciário da Beira Baixa (Portugal). Comunicaçōes do Instituto Geológico e Mineiro 82, 87-130.

Cunha, P.P., Martins, A.A., Daveau, S., Friend, P.F., 2005. Tectonic control of the Tejo river fluvial incision during the late Cenozoic, in Ródão - central Portugal (Atlantic Iberian border). Geomorphology 64, 271-298.

Cunha, P.P., Martins, A.A., Huot, S., Murray, A.S., Raposo, L., 2008. Dating the Tejo River lower terraces in the Ródão area (Portugal) to assess the role of tectonics and uplift. Geomorphology 102, 43-54.

De Abreu, L., Shackleton, N.J., Schönfeld, J., Hall, M., Chapman, M.R., 2003. Millennialscale oceanic climate variability off the Western Iberian margin during the last two glacial periods. Marine Geology 196, 1-20.

De Vicente, G., Cloetingh, S., Van Wees, J., Cunha, P.P., 2011. Tectonic classification of Cenozoic Iberian foreland basins. Tectonophysics 502 (1-2), 38-61.

Deprez, S., De Dapper, M., Almeida, N., De Paepe, P., Vermeulen, F., 2009. A geoarchaeological study of the historical placer gold exploitation of the Tagus River terrace of the Conhal (Nisa, Northeastern Alentejo, Portugal). In: De Dapper, M., Vermeulen, F. (Eds.), "Ol'Man River": Geo-archaeological Aspects of Rivers and River Plains. Proceedings of the International Colloquium, Ghent, 22-24 September 2006. Archaeological Reports Ghent University, pp. 311-332.

Duller, G.A.T., 2004. Luminescence dating of Quaternary sediments: recent advances. Journal of Quaternary Science 19, 183-192.
Escudero, B., Olmo, D., 1997. Resultados paleomagnéticos de la raña del Hespérico Meridional (Montoro, Córdoba). Geogaceta 21, 31-34.

GEPP, 1977. O Paleolítico. As primeiras comunidades humanas de caçadores recolectores. Grupo para o Estudo do Paleolítico Português. Edição do Museu Francisco Tavares Proença Júnior, Castelo Branco.

GEPP, 1978. O Paleolítico de Ródão. Aspectos e Métodos da Pré-História, 1. Trabalhos do GEAP, Lisboa, pp. 71-77.

GEPP, 1980a. Um acampamento do Homem de Neandertal nas margens do Tejo? Historia $15,38-43$.

GEPP, 1980b. Vilas Ruivas: um acampamento do Paleolítico Médio. História e Sociedade 7, 29-33.

Gutiérrez-Elorza, M., Peña-Monné, J.L., 1998. Geomorphology and late Holocene climatic change in Northeastern Spain. Geomorphology 23, 205-217.

Heinrich, H., 1988. Origin and consequences of cyclic icerafting in the Northeast Atlantic ocean during the past 130,000 years. Quaternary Research 29,142-152.

Huntley, D.J., Lamothe, M., 2001. Ubiquity of anomalous fading in K-feldspars and the measurement and correction for it in optical dating. Canadian Journal of Earth Sciences 38, 1093-1106.

Lamothe, M., Auclair, M., Hamzaoui, C., Huot, S., 2003. Towards a prediction of longterm anomalous fading of feldspar IRSL. Radiation Measurements 37, 493-498.

Lebreiro, S.M., Moreno, J.C., McCave, I.N., Weaver, P.P.E., 1996. Evidence for the Heinrich layers off Portugal (Tore Seamount: 391N, 121W). Marine Geology 131, 47-56.

Marks, A., Monigal, K., Zilhão, J., 2001. The lithic assemblages of the Late Mousterian at Gruta da Oliveira, Almonda, Portugal. In: Zilhão, J., Aubry, T., Carvalho, A.F. (Eds.), Les premiers hommes modernes de la Péninsule Ibérique. Instituto Português de Arqueologia, Lisboa, pp. 145-154.

Martins, A.A., Cunha, P.P., Huot, S., Murray, A.S., Buylaert, J.-P., 2009. Geomorphological correlation of the tectonically displaced Tejo River terraces (Gavião-Chamusca area, central Portugal) supported by luminescence dating. Quaternary International 199, 75-91.

Martins, A.A., Cunha, P.P., Buylaert, J.P., Huot, S., Murray, A.S., Dinis, P., Stokes, M., 2010a. K-feldspar IRSL dating of a Pleistocene river terrace sequence of the Lower Tejo River (Portugal, western Iberia). Quaternary Geochronology 5, $176-180$.

Martins, A.A., Cunha, P.P., Rosina, P., Oosterbeck, L., Cura, S., Grimaldi, S., Gomes, J., Buylaert, J.-P., Murray, A.S., Matos, J., 2010b. Geoarchaeology of Pleistocene open air sites in the Vila Nova da Barquinha - Santa Cita area (Lower Tejo River basin, central Portugal). Proceedings of the Geologists Association 121, 128-140.

Murray, A.S., Marten, R., Johnston, A., Martin, P., 1987. Analysis for naturally occurring radionuclides at environmental concentrations by gamma spectrometry. Journal of Radioanalytical and Nuclear Chemistry 115, 263-288.

Olley, J.M., Murray, A.S., Roberts, R.G., 1996. The effects of disequilibria in the uranium and thorium decay chains on burial dose rates in fluvial sediments. Quaternary Science Reviews 15, 751-760.

Oosterbeck, L., Grimaldi, S., Rosina, P., Cura, S., Cunha, P.P., Martins, A.A., 2010. The earliest Pleistocene archaeological sites in western Iberia: present evidences and research prospects. Quaternary International 223-224, 399-407.

Pais, J., Cunha, P.P., Pereira, D., Legoinha, P., Dias, R., Moura, D., Brum da Silveira, A., Kullberg, J.C., González-Delgado, J.A., 2012. The Paleogene and Neogene of Western Iberia (Portugal). A Cenozoic Record in the European Atlantic Domain. Springer Briefs in Earth Sciences. 158 pp.

Pérez-González, A., 1994. Depresión del Tajo. In: Gutiérrez Elorza, M. (Ed.), Geomorfología de España. Ed. Rueda, Madrid, pp. 389-436.

Pinilla, L., Pérez-González, A., Sopeña, A., Parés, J.M., 1995. Fenómenos de hundimientos sinsedimentarios en los depósitos cuaternarios del río Tajo en la cuenca de Madrid (Almoguera-Fuentidueña de Tajo). In: Aleixandre, T., Pérez-González, A. (Eds.), Reconstrucción de paleoambientes y cambios climáticos durante el Cuaternario. : Centro de Ciencias Medioambientales, 3. C.S.I.C, Madrid, pp. 125-139.

Raposo, L., 1986. Mustiero-Languedocence ou Languedocense? Arqueologia 14, 13-21. Raposo, L., 1987. Os mais antigos vestígios de ocupação humana Paleolítica na região de Ródão. Da Pré-história à História - Homenagem a Octávio da Veiga Ferreira. Editorial Delta, pp. 153-178.

Raposo, L., 1995a. Ambientes, territorios y subsistencia en el Paleolitico medio de Portugal. Complutum 6, 57-77.

Raposo, L., 1995b. O Paleolítico. In: Medina, J. (Ed.), História de Portugal, vol. 1. Clube Internacional do Livro, Lisboa, pp. 23-85.

Raposo, L., 1999. Foz do Enxarrique (Ródão, Portugal): preliminary results of the analysis of a bone assemblage from a Middle Palaeolithic open site. In: Gaudzinski, S., Turner, E. (Eds.), The Role of Early Humans in the Accumulation of European Lower and Middle Palaeolithic Bone Assemblages: Ergebnisse eines Kolloquiums (Romisch-Germanisches Zentralmuseum Forschungsinstitut fur Vor- und Fruhgeschichte Monographien, 42, pp. 367-379.

Raposo, L., 2000. The Middle-Upper Palaeolithic transition in Portugal. In: Stringer, C., Barton, R., Finlayson, C. (Eds.), Neanderthals on the Edge: 150th Anniversary Conference of the Forbes' Quarry Discovery, Gibraltar. Oxbow Books, Oxford, pp. 95-109.

Raposo, L., 2002. Um século de estudos no Paleolítico Médio em Portugal: balanço e perspectivas. Arqueologia e História 54, 25-39.

Raposo, L., Silva, A.C., 1981. Elementos de cultura material na estação paleolítica de Vilas Ruivas (Ródão). Arqueologia 4, 94-104.

Raposo, L., Silva, A.C., 1982. A campanha 541 de escavações de 1979 em Vilas Ruivas. Informação Arqueológica 2, 43-48

Raposo, L., Silva, A.C., 1983. A estação Paleolítica de Vilas Ruivas (Ródão) - campanha de 1979. O Arqueólogo Português, Lisboa, 4ª̣ série, vol. 1, pp. 15-38. 
Raposo, L., Silva, A.C., 1985a. A campanha de escavações de 1983 no Monte Famaco. Informação Arqueológica 5, 68-69.

Raposo, L., Silva, A.C., 1985b. A sala de arqueologia do Centro Municipal de Cultura de Vila Velha de Ródão. Arqueologia 11, 126-130.

Raposo, L., Silva, A.C., 1985c. A campanha de escavações de 1982 em Vilas Ruivas. Informação Arqueológica 5, 70.

Raposo, L., Silva, A.C., 1986. O estudo do Paleolítico de Ródão síntese dos conhecimentos actuais. Trebarvna II, 9-16.

Raposo, L., Silva, A.C., Salvador, M., 1985. Notícia da descoberta da estação Mustierense da Foz do Enxarrique (Ródão). I Reunião do Quaternário Ibérico, 2, pp. 79-90 (Proceedings), Lisboa.

Roucoux, K.H., de Abreu, L., Shackleton, N.J., Tzedakis, P.C., 2005. The response of NW Iberian vegetation to North Atlantic climate oscillations during the last $65 \mathrm{kyr}$. Quaternary Science Reviews 24, 1637-1653.

Sánchez Goñi, M.F., 2006. Interactions vegetation-climate au cours des derniers 425000 ans en Europe occidentale. Le message du pollen des archives marines. Quaternaire $17,3-25$.

Sánchez Goñi, M.F., Cacho, I., Turon, J.L., Guiot, J., Sierro, F.J., Peypouquet, J.P., Grimalt, J.O., Shackleton, N.J., 2002. Synchroneity between marine and terrestrial responses to millennial scale climatic variability during the last glacial period in the Mediterranean region. Climate Dynamics 19, 95-105.

Santisteban, J., Schulte, L., 2007. Fluvial networks of the Iberian Peninsula: a chronological framework. Quaternary Science Reviews 26, 2738-2757.

Santonja, M., Pérez-González, A., 1997. Los yacimientos acheulenses en terrazas fluviales de la Meseta Central española. In: Rodríguez, V.J. (Ed.), Cuaternario Ibérico, AEQUA, Huelva, Spain, pp. 224-234.

Santonja, M., Pérez-González, A., 2002. El Paleolítico inferior en el interior de la Península Ibérica. Un punto de vista desde la geoarqueología. Zephyrus 53-54, 27-77.
Silva, A., Pimenta, C., Lemos, F., Zilhão, J., Mateus, J., Raposo, L., Coutinho, M., 1981. Vilas Ruivas: um acampamento do Paleolítico Médio. Breve história dos trabalhos arqueológicos realizados em Vilas Ruivas. História e Sociedade 7, 29-33.

Silva, P., Palomares, M., Rubio, F., Goy, J., Hoyos, M., Martín-Serrano, A., Zazo, C., Alberdi, M., 1999. Geomorfología, estratigrafía, paleontología y procedencia de los depósitos arcósicos cuaternarios de la depresión Prados-Guatén (SW Madrid). Cuaternario y Geomorfología 13, 79-94.

Sohbati, R, Murray, A. Buylaert, J-P. Almeida, N., Cunha, P.P. 2012 Optically stimulated luminescence (OSL) dating of quartzite cobbles from the Tapada do Montinho archaeological site (east-central Portugal). Boreas 41, 452-462.

Spooner, N.A., 1992. Optical dating: preliminary results on the anomalous fading of luminescence from feldspars. Quaternary Science Reviews 11, 139-145.

Texier, J., Inizan, M.L., Roche, H., Dauvois, M., 1980. Préhistoire de la pierre taillé I. Terminologie et technologie. Antibes, Cercle de Recherches et d'Etudes Préhistorique. CREP, Nanterre. 120 pp.

Thomsen, K.J., Murray, A.S., Jain, M., 2011. Stability of IRSL signals from sedimentary Kfeldspar samples. Geochronometria 38, 1-13.

Westaway, R., Bridgland, D.R., Sinha, R., Demir, T., 2009. Fluvial sequences as evidence for landscape and climatic evolution in the Late Cenozoic: a synthesis of data from IGCP 518. Global and Planetary Change 68, 237-253.

Wintle, A.G., 1973. Anomalous fading of thermoluminescence in mineral samples. Nature 245, 143-144.

Zilhão, J., 2006. Chronostratigraphy of the Middle-to-Upper Paleolithic Transition in the Iberian Peninsula. Pyrenae 37, 7-84. 